American J. of Engineering and Applied Sciences 3 (1): 68-72, 2010

ISSN 1941-7020

(C) 2010 Science Publications

\title{
Analysis of Comparison between Unconfined and Confined Condition of Foamed Concrete Under Uni-Axial Compressive Load
}

\author{
${ }^{1}$ Mohd Zairul Affindy Abdul Rahman, ${ }^{2}$ Ahmad Mujahid Ahmad Zaidi and ${ }^{1}$ Ismail Abdul Rahman \\ ${ }^{1}$ Faculty of Civil and Environmental Engineering, \\ ${ }^{2}$ Faculty of Mechanical and Manufacturing Engineering, \\ University Tun Hussein Onn Malaysia, 86400, Parit Raja, Batu Pahat, Johor Malaysia
}

\begin{abstract}
Problem statement: Foamed concrete has become most commercial material in construction industry. People in industries were come out with the new mix design of foamed concrete to meet the specification and the requirements needed. Approach: This is because foamed concrete has the possibility as alternative of lightweight concrete for producing intermediate strength capabilities with excellent thermal insulation, freeze-thaw resistance, high-impact resistance and good shock absorption. Results: Currently Standard test to measure the compressive strength of foamed concrete is using standard unconfined compressive test. Several research has been conduct but the compressive strength using standard unconfined compressive test not capture true behavior of foamed concrete because it just achieved only low compressive strength and sample under compression failed due to brittle collapse of the sample. This study was analyzed the comparison between standard compressive test and confined compressive test. The confinement test introduced to prevent sample from brittle collapse. Foamed concrete cylindrical sample has been investigated under the standard compressive test for hard concrete (ASTM-C39). Based on the research, samples are produced under unconfined and confined condition. Analysis has been done and the result show that under standard compressive test, the sample failed due to early crack initiation and failed. Confinement condition was increase the compressive strength but this condition influence the result. Conclusion/Recommendations: Standard test is not suitable to capture the true behavior of foamed concrete, and to prevent the sample from brittle collapse during the test, new testing method was introduced to capture the true behavior of foamed concrete which is using Quasi Static Indentation Test. This test can be used to study about the behavior of foamed concrete before it can be implemented to its final application.
\end{abstract}

Key words: Foamed concrete, unconfined and confined compressive test, mode of failure

\section{INTRODUCTION}

Foamed concrete is now used widely in construction industries because all community around the world relies on factors as a safe, strong and simple building material. Research has been conduct to study the behavior of concrete to determine the material and structural properties and also how will these properties differ according to a different type of mixture and its composition and also to the different type of concrete. The compressive strength of foamed concrete is common performance measure for foamed concrete and normal concrete to determine its properties and also as quality control to make sure that the mix is meet the requirements. For the beginning, it has defined that foamed concrete is one of the lightweight concrete and it's referred to cellular material which is consisting of Portland cement, fine sand, water, foaming agent and compressed air (Dolton and Hannah, 2006). The different between foamed concrete and normal concrete is the use of aggregates in the foamed concrete was eliminated and been replaced by the homogenous cells created by air in the form of small bubble which utilize a stable air cell structure rather than traditional aggregate (Zaidi et al., 2008). It can be categorized as cellular material because it contains a higher amount of pores. Based on its morphology, foamed concrete can be easily known as a cellular material and the behavior must be same as cellular solid behavior. In this research, plain foamed concrete is made of a combination of fine sand, cement, water and foam. The target density for this plain foamed concrete is within

Corresponding Author: Ahmad Mujahid Ahmad Zaidi, Faculty of Mechanical and Manufacturing Engineering, University Tun Hussein Onn Malaysia, 86400, Parit Raja, Batu Pahat, Malaysia 
the range of $800-1000 \mathrm{~kg} \mathrm{~m}^{-3}$. In this research, confined condition is where the sample was confined with plastic wrappers. Six samples were produced then were test using standard compressive load. The unconfined samples also were produced with the same batch and also undergo the standard compressive load.

\section{MATERIALS AND METHODS}

In this study, plain foamed concrete is made of a combination of fine sand, cement, water and foam. The target density for this plain foamed concrete is within the range of $700-120 \mathrm{~kg} \mathrm{~m}^{-3}$. Below is the proposed design mix of foamed concrete (Table 1).

Uni-Axial Compressive loads test is performed to determine the behavior of materials under crushing loads. The samples compressed and deformation at various loads is recorded. The compressive strength test was performed based on compressive strength of cylinder concrete specimens-ASTM C39 standard. The purpose is to determine the compressive strength of cylinder foamed concrete (unconfined and confined). The method is limited to concrete having a density of at least $800 \mathrm{~kg} \mathrm{~m}^{-3}$ and 28 days compressive strength of molded cylinder is normally used in design.

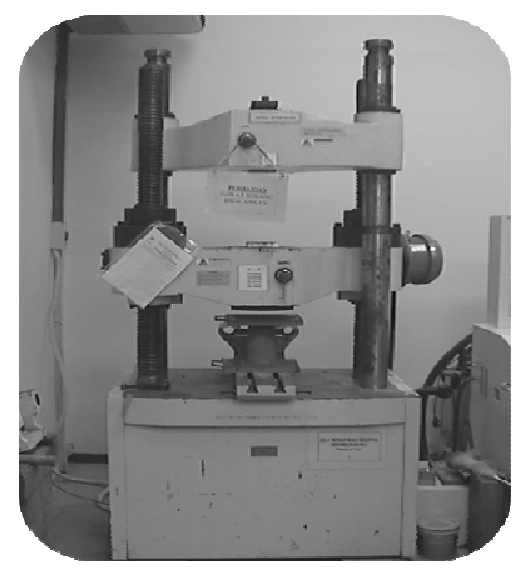

Fig. 1: Universal testing machine

Table 1: Mix design for foamed concrete

\begin{tabular}{ll}
\hline Subject & Quantity \\
\hline Dry density $\left(\mathrm{Kg} \mathrm{m}^{-3}\right)$ & 799 \\
Wet density $\left(\mathrm{Kg} \mathrm{m}^{-3}\right)$ & 940 \\
Sand: Cement: Water & $1: 1: 0.6$ \\
Cement $(\mathrm{Kg})$ & 79.2 \\
Dry sand $(\mathrm{Kg})$ & 79.2 \\
Water $(\mathrm{Kg})$ & 47.48 \\
Slurry density $\left(\mathrm{Kg} \mathrm{m}^{-3}\right)$ & 2005 \\
Foaming agent $(\mathrm{L})$ & 0.167 \\
Water (L) & 5.63 \\
Foam (L) & 122.18 \\
\hline
\end{tabular}

The specimen's size is 150 in diameter and $300 \mathrm{~mm}$ in height. Foamed concrete sample will be tested under compressive load to determine the behavior of foamed concrete. All specimens were loaded uni-axially in compression until failure using a hydraulic testing machine (universal testing machine-UTM) as shown in Fig. 1. From the result, we can get the maximum stress and also the displacement of the samples. Compressive stress and strain are calculated and plotted as a stressstrain diagram. The standard method for this test is according to standard test method for compressive strength of cylinder concrete specimens (ASTM: C39/C39M-01).

\section{RESULTS AND DISCUSSION}

Currently the conventional method to obtain the compressive strength of foamed concrete is using the normal standard unconfined uni-axial compressive test. Therefore several unconfined and confined compressive test have been done to obtained uni-axial compressive stress-strain curves. However, these entire tests were failed due to the brittle collapse of the sample. The result of the conventional compression test show that the compressive strength typically proportioned to achieve only low compressive strength which is believed it is not captured details behavior of foamed concrete due to the early cracked initiation. According to the behavior of foamed concrete under unconfined condition and confined condition, it seems clearly that standard compressive load test does not suitable to extract the properties of foamed concrete. From the beginning, unconfined condition under compressive load give the low compressive strength and failed due to early crack initation. Confined condition is proposed to give material supporting to prevent brittle collapse and will give more strength. Unfortunately, the confinemet condition still cannot prevent from brittle collapse but it reduce the crack occur and propagation of crack. The compressive strength increase, but the wrappers influnce the strenght of it.

Compressive strength: The strength of concrete originates from the strength of the hardening cement paste, which is, in turn, originates from hydration products (Popovics, 1998). The compressive strength of concrete is one of the most important technical properties. In this research, the compressive strength of foamed concrete under unconfined and confined condition is compared. Table 2 and 3 shows the results of foamed concrete under unconfined and confined compressive test. It shows that the compressive strength typically proportioned to achieve only low compressive strength. 
Am. J. Engg. \& Applied Sci., 3 (1): 68-72, 2010

Table 2: The result of unconfined compressive test of foamed concrete

\begin{tabular}{llllll}
\hline & & $\begin{array}{l}\text { Maximum } \\
\text { force }\end{array}$ & $\begin{array}{l}\text { Maximum } \\
\text { displacement } \\
(\mathrm{mm})\end{array}$ & $\begin{array}{l}\text { Compressive } \\
\text { strength } \\
\left(\mathrm{n} \mathrm{mm}^{-2} \mathrm{mpa}^{-1}\right)\end{array}$ & $\begin{array}{l}\text { Maximum } \\
\text { strain } \\
(\%)\end{array}$ \\
\hline Unconfined & SC1 & 15.59 & 4.80 & 0.88 & 1.60 \\
& UC2 & 16.03 & 4.89 & 0.91 & 1.63 \\
& UC3 & 14.34 & 5.83 & 0.81 & 1.94 \\
& UC4 & 15.53 & 7.29 & 0.88 & 2.43 \\
& UC5 & 17.00 & 7.87 & 0.96 & 2.62 \\
Average & UC6 & 14.81 & 7.69 & 0.84 & 2.56 \\
\hline
\end{tabular}

Table 3: The result of confined compressive test of foamed concrete

\begin{tabular}{|c|c|c|c|c|c|}
\hline Type & Sample & $\begin{array}{l}\text { Maximum } \\
\text { force } \\
\mathrm{KN}\end{array}$ & $\begin{array}{l}\text { Maximum } \\
\text { displacement } \\
(\mathrm{mm})\end{array}$ & $\begin{array}{l}\text { Compressive } \\
\text { strength } \\
\mathrm{n}\left(\mathrm{mm}^{-2} \mathrm{mpa}^{-1}\right)\end{array}$ & $\begin{array}{l}\text { Maximum } \\
\text { strain } \\
(\%)\end{array}$ \\
\hline \multirow[t]{6}{*}{ Confined } & CF1 & 17.78 & 5.47 & 1.01 & 1.82 \\
\hline & UC2 & 14.50 & 2.91 & 0.82 & 0.97 \\
\hline & UC3 & 16.50 & 6.14 & 0.93 & 2.05 \\
\hline & UC4 & 18.06 & 5.51 & 1.02 & 1.84 \\
\hline & UC5 & 18.47 & 5.86 & 1.04 & 1.95 \\
\hline & UC6 & 16.88 & 3.10 & 0.95 & 1.03 \\
\hline Average & & 17.03 & 4.83 & 0.96 & 1.61 \\
\hline
\end{tabular}

Generally the range of compressive strength is from 1$15 \mathrm{~N} \mathrm{~mm}^{-2}$ (Zaidi et al., 2008). Unconfined condition gives average of $15.55 \mathrm{kN}$ in maximum load while confined condition give $17.03 \mathrm{kN}$. The compressive strength is about 0.88 in average and 0.96 in average. Based on this result, confined condition just give higher compressive strength compared unconfined condition. This is because of function of the confinement itself. Based on the research, foamed concrete is a combination of soft and brittle material. The failure is caused by early crack initiation where brittle collapses were produced. The confinement condition has reduced and slows down the crack propagation. The crack produced in big piece and automatically the micro cracks were reducing. It also increases the maximum load and prevents the material from brittle collapse for temporary period. But the confinement itself also has influence the result of maximum compressive strength. The different between these two conditions is confinement condition give more compressive strength compared to unconfined. The displacement of the sample under compression shows that unconfined condition have higher displacement compared to confined condition. This is because of the displacement is related to the dense of air voids and also in line with the rupture of the cell. The crack propagation also affected the displacement under compression. Crack occurs in the early stage which produced in top part of the sample inline with increasing of the load. When these crack propagated, then its going too failed due to early crack initiation. The universal testing machine automatically stopped the test and it's considered as failed (Abdul Rahman et al., 2008).

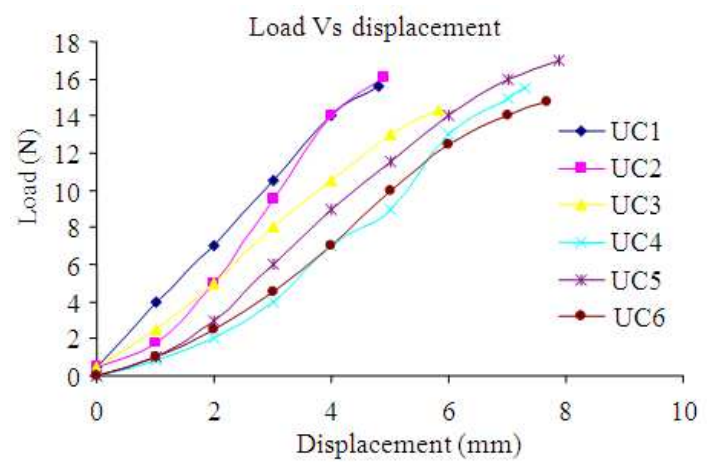

Fig. 1: Compressive behavior of cylinder foamed concrete (unconfined) under load-displacement curve

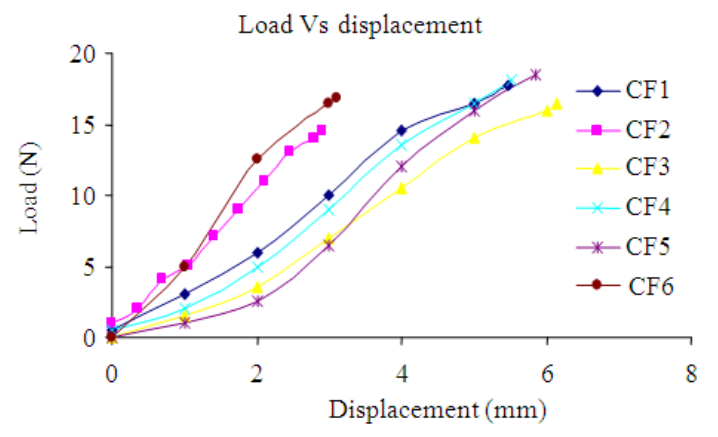

Fig. 2: Compressive behavior of cylinder foamed concrete (confined) under load-displacement curve

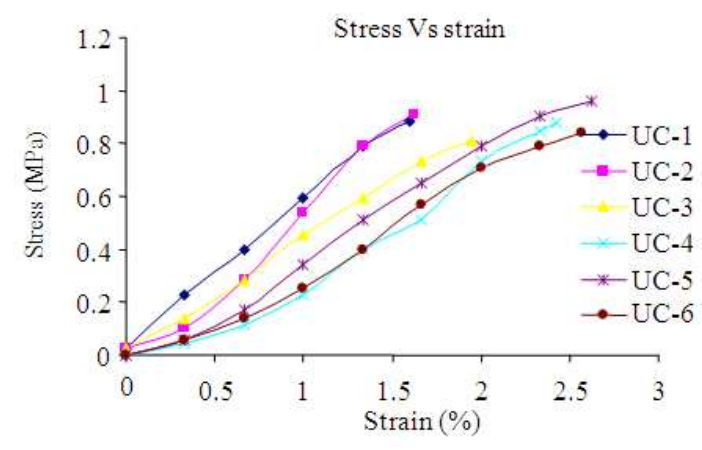

Fig. 3: Compressive behavior of cylinder foamed concrete (unconfined) under stress-strain curve

Figure 1 and 2 shows the curve of load versus displacement. What we can observe from here that the curve just give the same pattern. There is not much different about it and the only thing here to look out is the displacement. If the sample were under confined condition, the displacement will reduce compared to unconfined condition. Explanation about it is because 
of the crack occurring and propagated parallel to the load. Confinement reduce crack and give less displacement depend on the wrapping material and condition. Figure 3 and 4 shows the stress-strain curve. In cellular material, the compressive stress-strain behavior can be simplified into three regimes. Due to the cellular behaviors, Fig. 5, this test shows it was only going to an elastic regime which is the initial stage. The curve supposed continue to next stage, plateau regime up to the densification strain and the densification regime, whereby the stress increases rapidly with the strain (Zaidi et al., 2008). Here, the plateau stress will become the compressive stress of the foamed concrete.

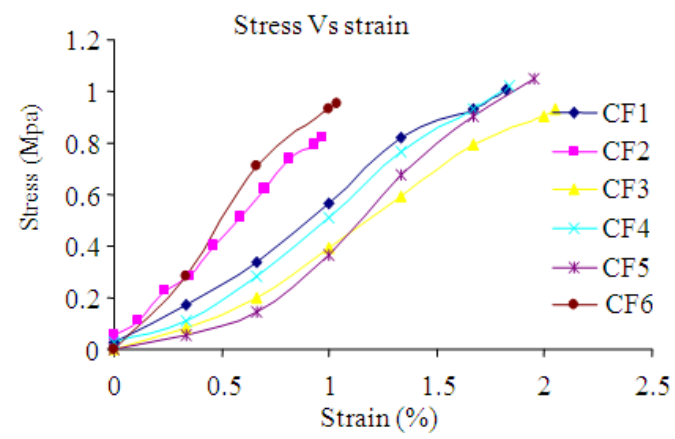

Fig. 4: Compressive behavior of cylinder foamed concrete (confined) under stress-strain curve

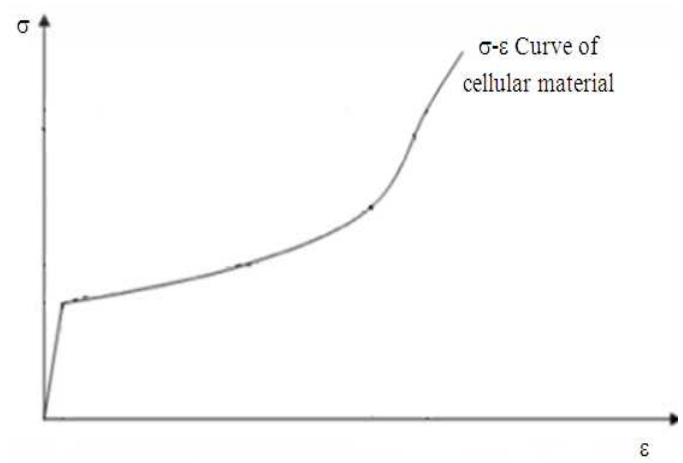

Fig. 5: Stress-strain curve of cellular material

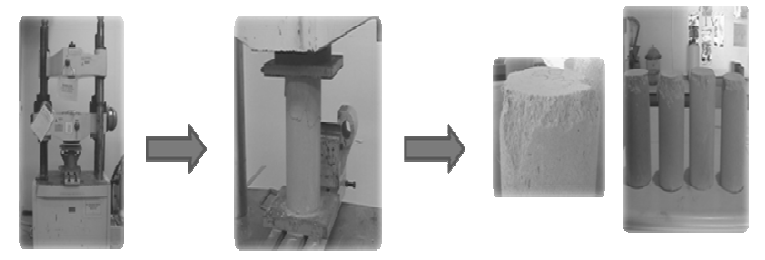

Fig. 6: Failure modes of plain foamed concrete (unconfined)
Based on this, it is note that the densification strain plays an important role for the determination of the plateau stress. There are various methods to determine the densification strain, where densification strain is determined by the intersection of the tangents between the plateau stress regime and densification regime, densification strain is determined as the strain at the last minimum stress before the stress increase rapidly, densification strain is determined through the strain at which slope of the tangents is equal to the elastic regime and densification strain is determined using the energy absorption efficiency-strain curves (Zaidi et al., 2008). The method above is the relationship between energy absorption efficiency and strain provides consistency and reliable result (Zaidi et al., 2008).

Mode of failure: Figure 6 and 7 shows the failure modes of the plain foamed concrete after the compression test. Figure 6 is under unconfined condition while Fig.7 under confined condition. From Fig. 7 what we can observed is the failure pattern is same where the crack just occur the top part of the sample. What happened here is just of brittle collapse. Confined condition just produced bigger piece of crack but still remain at the top part of the sample. Figure 8 and 9 shows us the top part failure of foamed concrete under compressive load. During the test, as the load reached to $90 \%$ of the ultimate value, one may hear slight crack on the top part of the sample. It was clearly seen that most of the cracks were emcompass on the top part of cylinderical sample. As the load continued to be added, the cylinder suddenly collapsed with all the cracks occur in the top part of the cylinder. The unconfine compression test does not make the collapse extended through the whole length of the cylinder. Figure 8 shows the failure modes of the unconfined compressive test as a top part failure due to early cracks initation (Abdul Rahman et al., 2008). According to BSEN 12390-3:2002, testing hardened concrete, mode of failure of these two condition is not have any similirarity compared to the satisfactory failure (British Standard, 2002). Figure 9 also shows the failure between unconfined and confined condition of foamed concrete.

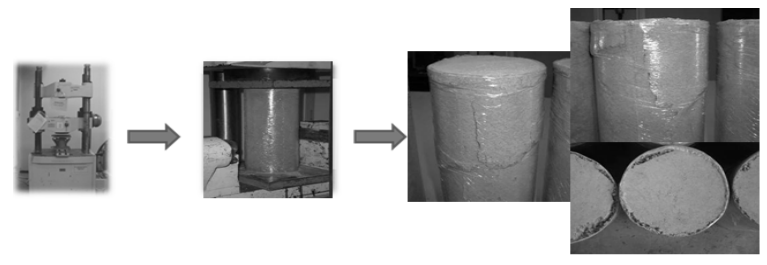

Fig. 7: Failure modes of plain foamed concrete (confined) 

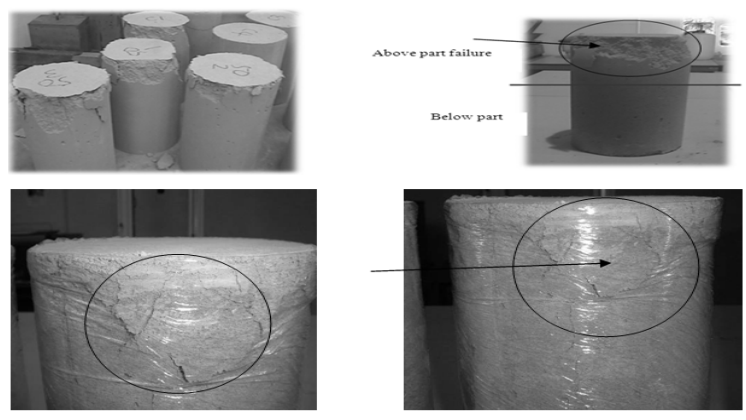

Fig. 8: Part of failure of foamed concrete

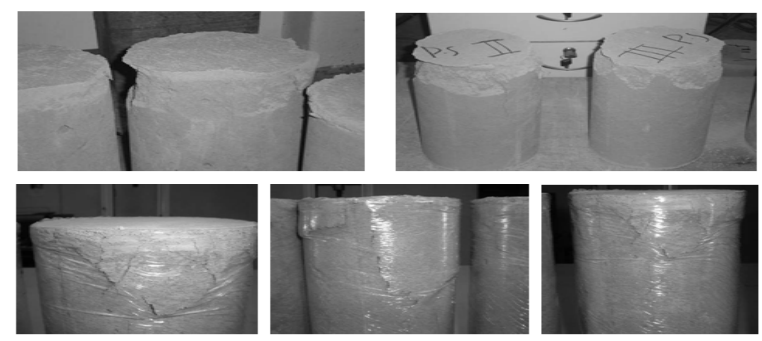

Fig. 9: The mode of failure between unconfined and confined condition

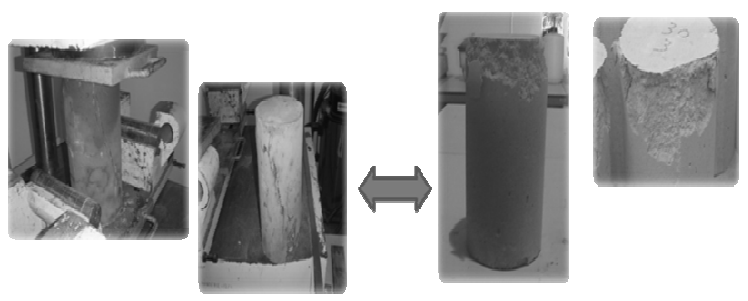

Fig. 10: Comparison failure modes compared to natural concrete

Figure 10 shows the failure mode of normal concrete where the crack of normal concrete appear along the length of the sample.This is tha satisfactory failure for concrete. Cylinderical concrete specimens generally fail along a diagonal plane, where the angle of rupture called, shear plane or plane of rupture. It is measure from the horizontal. Relatively, all this test were go under the same type of test, standard compressive load based on ASTM C-39 testing of hardened concrete (ASTM International, 2002).

\section{CONCLUSION}

For conclusion, compressive load test doesn't suitable to applied to foamed concrete. This is because under this standard compressive load, it doesn't captured the real properties of foamed concrete. As an alternatively, research have been conducted to proposed new guideline how to capture the behavior of foamed concrete under compressive load. Quasi static indentation test are introduced with new guideline also design to captured the properties and behavoir of foamed concrete. This guide line is very usefull to help researcher in developing the research in foamed concrete.

\section{REFERENCES}

Abdul Rahman, M.Z.A., A.M. Ahmad Zaidi and I. Abdul Rahman, 2008. Investigation of physical behavior of foamed concrete under unconfined compressive test. Proceeding of the $3 \mathrm{rd}$ International Conference on Post Graduate Education, ICPE-3 2008: Multidisciplinary Education, Dec. 16-17, Pulau Pinang, Malaysia, pp: $1-9$.

ASTM International, 2002. Ready-Mixed Concrete: ASTM Standard and Related Information 2nd Edn., ASTM International, ISBN: 080312841X, pp: 239.

British Standard, 2002. BS EN 12390-3:2002, Testing hardened concrete-part 3: Compressive strength of test specimens. http://www.techstreet.com/cgibin/detail?product_id $=1111208$

Dolton, B. and C. Hannah, 2006. Cellular concrete: Engineering and technological advancement for construction in cold climates. Proceeding of the 2006 Annual General Conference of the Canadian Society for Civil Engineering, May 23-26, Calgary Alberta, Canada, pp: 1-11. http://www.cematrix.com/docs/technical/papers_ce llularconcrete.pdf

Popovics, S., 1998. Strength and Related Properties of Concrete A Quantitative Approach. John Wiley and Sons, Inc., ISBN: 0471149039, pp: 535.

Zaidi, A.A.M., A.I. Rahman and N.H.A. Zaidi, 2008. Behavior of fiber reinforced foamed concrete: Indentation test analysis. Proceeding of the Seminar on Geotechnical Engineering, Dec. 27-27, University Tun Hussein Onn Malaysia, Johore, Malaysia, pp: 92-101. 